\title{
Oviposition deterrent activities of some plant extracts against tomato leaf miner, Tuta Absoluta meyrick (Lepidoptera: Gelehiidae)
}

\begin{abstract}
Tuta absoluta Meyrick (Lep.:Gelechiidae) is a very serious pest worldwide, causing damage to tomatoes. In this study, the oviposition deterrence efficacy of extracts obtained from Tanacetum vulgare L. (Asteracea), Tanacetum parthenium L. (Asteracea), Aleo vera (L) (Liliaceae), Melaleuca alternifolia (Maiden\&Betce)(Myrtaceae) and Juglans regia L. (Juglandecae) on Tuta absoluta Meyrick (Lep.:Gelechiidae) was investigated. Eggs laid daily were placed in Petri dishes and observed until pupa. After larvae become pupae were distinguished male or females using a stereomicroscope. After that, two male and one female were released within cage to couple during 24h. Adults were put into cages containing with extract treated plant. The experiment was replicated four times including control. Daily monitoring was conducted for fourteen days and the total number of eggs was recorded. According to the results obtained, the extract of T. parthenium showed the highest deterrence effect $(98.29 \%)$ at the highest concentration $(20 \%)$. The extracts of $T$. vulgare and $A$. vera, were the deterrence effect $95.43 \%$ and $94.68 \%$ in the same concentration respectively. It was reported that the deterrence effect of Gamatol, fungatol and J. regia were $92.54 \%, 86.52 \%$ and $79.94 \%$ at the highest concentration respectively. The percent oviposition deterrence was $89.37 \%$ at Neem Azal T/S. The percent oviposition deterrence increased with increase in concentration of plant materials.
\end{abstract}

Keywords: Tuta absoluta, antimicrobial, tomatoes, gammatol, flavonoids, plant material, botanical insecticides, fungi
Volume 7 Issue 6 - 2019

\section{Pervin Erdogan}

Plant Protection Central Research Institute,Turkey

Correspondence: Pervin Erdogan, Plant Protection Centra Research Institute, Gayret Mah. Fatih Sultan Mehmet Bul. 06 I72 No. 66 Yenimahalle-Ankar, Turkey, Tel +90(312) 3445993 (4 line)/I207, Fax +90(312) 315 I53।, Email pervin_erdoga@hotmail.com

Received: November 10, 2019 | Published: November 19, 2019

\section{Introduction}

Tomato (Lycopersicon esculentum Mill.), which has a very important place in human nutrition, is cultivated almost everywhere in the world. Tomato is grown in almost every region of Turkey. It is an important export product for Turkey. In tomato cultivation, Liriomyza spp. (Burgess) (Diptera: Agromyziidae), Tetranychus spp. (Acarina: Tetranychidae), Aphis spp. Thrips spp. (Thysanoptera: Thripidae) are identified as significant pests. ${ }^{1}$ Tomato exclusion of host plants of T. absoluta are potatoes, eggplants, pepino, artichokes, beans and tobacco. ${ }^{2}$ T. absoluta, which has high reproductive power, gives $10-$ 12 offspring per year under suitable conditions (in Mediterranean climate) and completes one off in 30-35 days. One female leaves 260 eggs during her life. ${ }^{3}$ The larvae are damaged in all parts of the tomato plant except the root, especially in the leaf and in every phenological period. In addition, the fungi and bacteria enter the galleries and make fruit unusable. Tomato moth reduces the quality of the product in tomatoes grown in greenhouses and outdoors and causes high $(50-100 \%)$ product loss in heavily contaminated areas. ${ }^{4}$ When T. absoluta was determined in Turkey in 2009, this pest has become the main pest in the provinces where tomato is grown. $T$. absoluta caused high rate of product losses and adversely affected tomato exports. Insecticide is used extensively to control $T$. absoluta. The widespread use of insecticides has improved resistance to $T$. absoulta, and their toxicity endangers health farm operators, animals and food consumers. Because of the negative effects of pesticides, scientists have focused on different methods to control pests. The researcher has reviewed the use of plant compounds such as essential oils, flavonoids, alkaloids having anti-insect effects. Plant compounds effect on insects in different ways, namely insecticide, repellents, anti feeding, oviposition deterrence and growth retardants. Botanical insecticides effect only target insects, not destroy natural enemies and provide residue free food and safe environment.

Tea tree, M. alternifolia is a native to Australia. Tea tree oil has antimicrobial and anti-inflammatory properties. ${ }^{5} \mathrm{~J}$. regia is a cosmopolitan tree species, and its leaves are used for medicinal purpose. The kernels contain a wide variety of flavonoids, phenolic acids and related polyphenols, which have good antioxidant, antiatherogenic, anti-inflammatory and anti-mutagenic properties. ${ }^{6}$ Feverfew, T. parthenium is a medicinal plant traditionally used for the treatment of fevers, migraine headaches, rheumatoid arthritis, stomachaches, toothaches, insect bites, infertility, and problems with menstruation and labor during childbirth. ${ }^{7} T$. vulgare is a perennial herb that has been used to treat multiple ailments. Regional variability of the chemical composition of $T$. vulgare essential oils is well-known. ${ }^{8} A$. vera is one of the most important medicinal plant capable of withstanding harsh environmental conditions such as lack of water and high temperatures. ${ }^{9}$ The aim of study to determine oviposition deterrent effect the extracts of M. alternifolia (Gammatol and Fungatol), T. parthenium T. vulgare, A. vera and J. regia on $T$ absoluta. 


\section{Material and methods}

\section{Tomato leaf miner culture}

T. absoluta was collected as larvae from tomato greenhouses in Ankara. The collected larvae of T. absoluta were placed in the cage $(50 \times 50 \times 30 \mathrm{~cm})$ with tomato plant. Newly emerged adults were transferred into another cage containing tomato plant. Tomato plant used in this study was grown in greenhouse. The joker variety tomato was used in stock culture of T. absoluta and the experiments.

\section{Plant extracts}

The plants T. parthenium T. vulgare were collected during 2016 in around Ankara province. Both plants were collected while actively growing at the flowering stage. The leaves, flowers and stems of the plants were used to obtain the extract. Only the leaves of J. regia plant were used. A. vera was grown in plots at room conditions. Gammatol and Fungatol obtained from $M$. alternifolia were supplied from Australia. Neem Azal T/S used as positive control was purchased from the company.

\section{Preparing the crude extracts}

Plant material were cut at level and whole plant was used for extraction. Than plant material were allowed to dry in laboratory conditions. Oven-dried leaves were ground to a fine powder. For extraction, $200 \mathrm{~g}$ of powdered plant materials and $400 \mathrm{~mL}$ of ethanol $(80 \%)$ were added to the dried powder for 72 hours. The above mixture placed into Sox let for 5-6 hrs. After filtering through a Bucher funnel and Whatman No.1 filter paper, the extracts were concentrated under low pressure using rotary evaporator $\left(50-60^{\circ} \mathrm{C}\right)$. Crude extract was keep at $4{ }^{\circ} \mathrm{C}$ in glass vials to be used as stock plant extract.

\section{Oviposition deterrent assay}

Daily laid eggs were placed in petri dishes $(3 \mathrm{~cm})$ containing leaves tomato plant. Per dishes, one egg was placed, and eggs were observed daily until pupa. Individuals were distinguished male or females using a stereomicroscope on the pupa stage. After that two male and one female were released within a cage $(15 \times 15 \times 10 \mathrm{~cm})$ lined with tulle without tomato plant to couple during $24 \mathrm{~h}$. After $24 \mathrm{~h}$, adults were placed into cages containing tomato plants with extract treated. The experiment was replicated four times including control. Daily monitoring was conducted for fourteen days and the total number of eggs was recorded. For these tests, one female and two males were released within cage $(30 \mathrm{~cm} \times 30 \mathrm{~cm} \times 30 \mathrm{~cm})$ and allowed to mate. After that, the extracted plant was left into the cage. The applications of the extract were sprayed using a small hand sprayer. Two concentrations were prepared by using distilled water to obtain concentrations of $5 \%, 10 \%$ and $20 \%$. Control treatments were used distillated water; experiments were conducted with four replications. The experiment was completely randomized and counts were performed daily for 14days. After $24 \mathrm{~h}$, the number of eggs deposited in each plant was counted and recorded.

\section{Statistical analysis}

The obtained results were submitted to a variance analysis and the mean values were compared by Duncan's test $(\mathrm{P}=0.05)$ calculated by the program SPSS 20.6.

Percent oviposition deterrent effect (PODE) was calculated according to the following method.
$\mathrm{NE}$ in control - NE in treated

PODE $=$ X100

$\mathrm{NE}$ in control

Index of egg laying (IE) was calculated according to the following method.

$\mathrm{NE}$ in control - NE in treatment

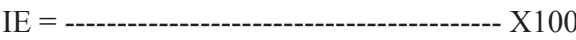

$\mathrm{NE}$ in control+ $\mathrm{NE}$ in treatment

Where NE is the number of eggs laid.

\section{Results and discussion}

The data obtained from the experiment are shown in Table 1. According to Table 1, the highest index of egg laying was at concentrations $10 \%$ and $20 \%$ extract of $T$. vulgare. This value fallowed the extract of extract of $A$. vera. The smallest index of egg laying was the concentration at $0.50 \%$ extract of Gamma-T-ol. The increased index of egg laying depending on concentrations. Statistical analysis showed importance differences between the concentrations. Accordingly, the highest concentrations T. vulgare $(10 \%, 20 \%)$ T.parthenium (20\%), A.vera (10\%, 20\%), Gammatol (2.00\%), Fungatol (3.50) and Neem Azal T/S were in the same groups ( $\mathrm{F}=1.423$; $\mathrm{p}=0.05$ ). The largest oviposition deterrent effect was at the highest concentrations $(10 \%, 20 \%)$ extract of T. vulgare while the smallest oviposition deterrent effect was at $0.50 \%$ extract of Gammatol. It was determined that statistical analysis showed the highest concentrations T. vulgare $(10 \%, 20 \%)$ T.parthenium $(20 \%)$, A.vera $(10 \%, 20 \%)$, Gammatol (2.00\%), Fungatol (3.50) and Neem Azal T/S formed in the same group $(\mathrm{F}=35.148 ; \mathrm{p}=0.05)$ (Table 2).

Table I Plants used in ovposition effect on Tuta absoluta

\begin{tabular}{lll}
\hline Scientific name & Family name & Tissue used \\
\hline Tanacetum parthenium $L$ & Asteracea & Flawers, leaves, buds \\
Tanacetum vulgare $L$. & Asteracea & Flawers, leaves, buds \\
Aleo vera $(L)$. & Liliaceae & Leaves \\
Juglans regia $L$. & Juglandecae & Leaves
\end{tabular}

Table 2 Index of egg laying and percent ovicidal percent oviposition deterrent effect of some plants crude extracts against Tuta absoluta eggs

\begin{tabular}{|c|c|c|c|}
\hline Treatment & $\begin{array}{l}\text { Concentrations } \\
(\%)\end{array}$ & $\begin{array}{l}\text { Index of egg } \\
\text { laying (\%) }\end{array}$ & $\begin{array}{l}\text { Oviposition } \\
\text { deterrent effect (\%) }\end{array}$ \\
\hline \multirow{4}{*}{ Gammatol } & 0.50 & $16.95 \pm 0.263 d$ & $28.63 \pm 0.363 c$ \\
\hline & 1.00 & $56.70 \pm 0.535 b c$ & $69.28 \pm 0.34 \mathrm{I} b$ \\
\hline & 2.00 & $79.10 \pm 0.327 \mathrm{ab}$ & $92.54 \pm 0.18 \mathrm{Ia}$ \\
\hline & 1.25 & $22.42 \pm 0.285 c$ & $35.50 \pm 0.342 c$ \\
\hline \multirow{2}{*}{ Fungatol } & 2.50 & $55.90 \pm 0.565 b c$ & $69.69 \pm 0.214 b$ \\
\hline & 3.50 & $76.30 \pm 0.327 b$ & $86.52 \pm 0.13 \mathrm{la}$ \\
\hline \multirow{4}{*}{ Aleo vera } & 5 & $58.94 \pm 0.379 b c$ & $73.90 \pm 0.312 b$ \\
\hline & 10 & $79.93 \pm 0.456 \mathrm{ab}$ & $86.75 \pm 0.157 a$ \\
\hline & 20 & $91.39 \pm 0.25 \mathrm{Ia}$ & $94.68 \pm 0.123 a$ \\
\hline & 5 & $23.02 \pm 0.298 c$ & $33.43 \pm 0.33 \mathrm{Ic}$ \\
\hline \multirow{2}{*}{ Juglans regia } & 10 & $49.33 \pm 0.218 c$ & $65.62 \pm 0.254 b c$ \\
\hline & 20 & $67.29 \pm 0.28 \mathrm{Ib}$ & $79.94 \pm 0.378 b$ \\
\hline
\end{tabular}


Table Continues...

\begin{tabular}{llll}
\hline Treatment & $\begin{array}{l}\text { Concentrations } \\
(\%)\end{array}$ & $\begin{array}{l}\text { Index of egg } \\
\text { laying (\%) }\end{array}$ & $\begin{array}{l}\text { Oviposition } \\
\text { deterrent effect (\%) }\end{array}$ \\
\hline & 5 & $58.68 \pm 0.34 \mathrm{lbc}$ & $72.87 \pm 0.298 \mathrm{~b}$ \\
$\begin{array}{l}\text { Tanacetum } \\
\text { vulgare }\end{array}$ & 10 & $87.87 \pm 0.263 \mathrm{a}$ & $92.62 \pm 0.189 \mathrm{a}$ \\
& 20 & $91.47 \pm 0.143 \mathrm{a}$ & $95.43 \pm 0.154 \mathrm{a}$ \\
Tanacetum & 10 & $70.87 \pm 0.135 \mathrm{ab}$ & $74.05 \pm 0.23 \mathrm{lb}$ \\
parthenium & 20 & $76.59 \pm 0.148 \mathrm{ab}$ & $91.46 \pm 0.194 \mathrm{a}$ \\
Neem Azal & 0.05 & $96.77 \pm 0.189 \mathrm{a}$ & $98.29 \pm 0.19 \mathrm{la}$ \\
T/S & & $88.98 \pm 0.21 \mathrm{la}$ & $89.37 \pm 0.23 \mathrm{la}$ \\
\hline
\end{tabular}

*Means within rows followed by the same uppercase letter are not significantly different (Duncun's multiple range test)

This study investigates the oviposition deterrent effect of the extracts of M. alternifolia (Gammatol and Fungatol), T. parthenium T. vulgare, A. vera and $J$. regia on $T$ absoluta. The all extracts were found to have strong oviposition deterrent effect on $T$ absoluta. Especially $T$. parthenium and $T$. vulgare showed that the highest oviposition deterrent effect on T. absoluta. There is no literature about the extract of these extracts effect on $T$. absoluta. This study is the first record to determine oviposition deterrent effect on $T$. absoluta. There are studies which conducted by using different plant extracts. For example, Barthelemy et al. ${ }^{10}$ revealed that the extracts of Ocimum gratissimum L. and $O$. basilicum L. (Lamiaceae) significantly reduced T. absoluta oviposition behavior on tomato plant. Azadirachtin caused decrease of egg-laying capacity of T. absoluta. ${ }^{11}$ On the contrary, it was revealed that the number of eggs laid by $T$. absoluta females on the treated leaves did not differ significantly from the control, with the exception of leaves treated with zeolits. ${ }^{12} T$. parthenium and $T$. vulgare are medicinal plants. There are many studies on the effect of T. parthenium and T. vulgare extracts on other insects. Goldstain \& Hahn ${ }^{13}$ revealed that aqueous the extract $T$. vulgare reduced feeding on cabbage leaf disks on Pieris rapae L. The same study was determined that aqueous the extract $T$. vulgare extract found that the insect lay less eggs than the control. The extracts of $T$. parthenium had antinociceptive and anti-inflammatory effects without altering the normal behavior of the mice and rats. ${ }^{14}$ Erdogan \& Yildırım ${ }^{15}$ reported that extracts of $T$. parthenium had the highest mortality effect on $M$. persicae the highest concentration (12\%). The extract of pyrethrum consists of many organic substances such as pirethrin, which exhibited insecticidal properties. Pirethrin was used as insecticide since ancient times. Particularly, pirethrin was used to control Thrips spp. and Aphids spp.

Tea tree oil has been used to control agricultural pests since the past. Halbert revealed that tea tree oil has toxic and repellent effect on pests. Bayindir et al. ${ }^{16}$ reported that Gammatol had insecticidal effect on T. absoluta. The same authors revealed that the commercial production named Gammatol and Gammatol plus neem showed negative effective on reproductively and development of $M$. persicae. In addition, Liao et al. ${ }^{17}$ revealed that $M$. alternifolia essential oil was shown to possess the fumigant toxicity against Sitophilus zeamais (Motsch) [Coleoptera: Curculionidae] and the same oils was the most effective compound for fumigant toxicity. The same study it was determined that terpinen-4-ol was the most effective compound for fumigant toxicity against $S$. zeamais. In another study, the extracts obtained from tea tree and named Gammatol and Fungatol showed the highest toxic effect on M. persicae, Aphis gossypii Glover, Tetranychus urticae $\mathrm{Koch}^{18,19} \mathrm{~J}$. regia has good antioxidant, anti-atherogenic, anti- inflammatory and anti-mutagenic properties. ${ }^{6}$ Leaf extract of $J$. regia has both insecticidal, bactericidal and antimicrobial properties. ${ }^{20}$ Erdogan and Yilmaz ${ }^{21}$ reported that the extract of walnut leaves showed the highest rate acaricidal effect on Tetranychus urticae Koch ((Acari: Tetranychidae). It was determined that walnut leaf extract had both contact and systemic effect on Tetranychus cinnabarinus (Boisd) and Tetranychus viennensis Zacher (Acari: Tetranychidae). A. vera is one of the most important medicinal plants, including enzymes, choline, amino acids, sugars, minerals, metabolic and phenolic compounds..$^{22}$ There a few study effect on extract of $A$. vera on insects. For example, Sarwar ${ }^{23}$ reported that extract of A. vera showed the highest effect on larva of Musca domestica. In addition, extract of $A$. vera had repellent effect Sitophilus oryzae L. In another study, it was revealed that the extract of $A$. vera showed the highest mortality rate on Sitotrage cerealella L. Lep.:Gelechiidae). Zhang et al. ${ }^{24}$ reported that the extracts $A$. vera coused strong acaricidal and repellent effect on Tetranychus cinnabarinus Boisduval (Acarina:Tetranychidae). ${ }^{25}$

\section{Conclusion}

It was determined that the oviposition deterrent effect of extracts of T. vulgare, T.parthenium, A.vera, Gammatol and Fungatol showed on T. absoluta. This study is the first report about oviposition deterrent of some extracts (T. vulgare, T.parthenium, A.vera, Gammatol and Fungatol) on T. absolta. According to the results of this study, these plant extracts may be used to control T. absoluta. Further study is needed to identify the active component of these plant extracts responsible for insecticidal activities under controlled and field conditions.

\section{Funding}

None.

\section{Acknowledgements}

None.

\section{Conflicts of interest}

The author declares that there is no conflict of interest.

\section{References}

1. Anonymous. Technical Instruction for Integrated Control of Covered Vegetables. 2011:42-47.

2. Pereyra PC, Sánchez NE. Effect of two solanaceous plants on developmental and population parameters of the tomato leaf miner (Tuta absoluta Meyrick) (Lepidoptera: Gelechiidae). Neotropical Entomology. 2006;35:671-676.

3. Franca FH. Por Quanto Tempo Conseguiremos Conviver Com a Traca-Do Tomateiro. Hortic Bras. 1993;11:176-178.

4. EPPO. Data sheets on quarantine pests. 2005.

5. Carson CF, Hammer KA, Riley TV. Melaleuca alternifolia (Tea Tree) Oil: a Review of Antimicrobial and Other Medicinal Properties. Clin Microbiol Rev. 2006;19(1):50-62.

6. Martínez ML, Labuckas DO, Lamarque AL, et al. Walnut (Juglans regia L.): genetic resources, chemistry, by-products. Journal Sci Food Agric. 2010;90(12):1959-1967

7. Pareek A, Suthar M, Rathore GS, et al. Feverfew (Tanacetum parthenium L.): A systematic review. Pharmacogn Rev. 2011;5(9):103-110. 
8. Coté H, Boucher MA, Pichette A, et al. Anti-Inflammatory, Antioxidant, Antibiotic, and Cytotoxic Activities of Tanacetum vulgare L. Essential Oil and Its Constituents. Medicines (Basel). 2017;4(2):34.

9. Vegag A. Aloe vera (aloe barbadensis miller) as a component of functional foods. Revista Chilena de Nutricin. 2005;32(3):1-14.

10. Yarou BB, Bawin T, Boullis A, et al. Oviposition deterrent activity of basil plants and their essentials oils against Tuta absoluta (Lep.:Gelechiidae). Environmental Science and Pollution Research. 2018;25(30):29880 29888 .

11. Tome HVV, Martins JC, Correa ES, et al. Azadirachtin avoidance by larvae and adult females of the tomato leaf miner Tuta absoluta. Crop protection. 2012;46:63-69.

12. De Smedt C, Van Damme V, De Clercq P, et al. Insecticide Effect of Zeolit on the Tomato Leafminer Tuta absoluta (Lepidptera: Gelechiidae). Insects. 2016;7(4):72.

13. Goldstain JH, Hahn SP. Antiefeedant and ovippsition deterrent activity of an aqueous extract of Tanacetum vulgare L. on two Cabbage Pests. Enviromental Entomology. 1992;21(4):837-844.

14. Jain NK, Kulkarni SK. Antinocicetive and anti-inflammatory effects of Tanacetum parthenium L. extract in mice and rats. Journal of Ethnopharmacology. 1999;68:251-259.

15. Erdogan P, Yildırım A. Insecticidal Activity of Three Differen Plant Extracts on the Green Peach Aphid [(Myzus persicae Sulzer) (Hemiptera: Aphididae)]. Journal of the Entomological Research Society. 2016;18(1):27-35.

16. Bayındır A, Özger Ş, Karaca İ, et al. Effects of some plant extracts on Tuta absoluta (Meyrick) (Lepidoptera: Gelechiidae) under laboratory conditions. Advances in Food Sciences. 2015;37(3):132:137.
17. Liao M, Xiao JJ, Zhou LJ, et al. Insecticidal Activity of Melaleuca alternifolia Essential Oil and RNA-Seq Analysis of Sitophilus zeamais Transcriptome in Response to Oil Fumigation. PLos ONE. 2016;11(12) 1:e0167748.

18. Kasap I, Kok S, Hassan E. Effect of Fungatol and Gamma-T-ol from Melaleuca alternifolia (Maiden \& Betche) Cheel on Aphis gossypii Glover (Hemiptera: Aphididae) and Tetranychus urticae Koch (Acari: Tetranychiᄀdae). Turkish Journal of Entomology. 2016;40: 117-123.

19. Kok S, Kasap I. Natural Insecticides Effects of Two Different Plan Extract on Green Peach Aphid, Myzus persicae Sulzer 1776 (Hemiptera Aphididae). Conscious Healthy Life Journal. 2016;12:209-215.

20. Zhang Z. Mites of Greenhouses; Identification, Biology and Control. Wallingford, UK. CABI Publishing; 2003:18.

21. Erdogan P, Y1lmaz BS. Acaricidal Activity of Extracts of Juglans regia L. on Tetranychus urticae Koch (Acari: Tetranychidae. Journal of Food Science and Engineering. 2017;7(1-16).

22. Raksha B, Pooja S, Babu S. (Bioactive compounds and medicinal properties of Aleo vera L. Journal of Plant Sciences. 2014;2(3):102-107.

23. Sarwar M. The inhibitory properties of organic pest control agents against aphid (Aphididae:Homoptera) on Canola Brassica napus L. (Brassicaceae) Under field enviroment. International Journal of Scientific Research in Environmental Sciences. 2013;1(18):195.

24. Zang Z, Ding L, Li M, et al. Action modes of Aleo vera L. extracts against Tetranychus cinnabarinus Boisduval (Acarina: Tetranychidae) Agricultural Science. 2013;4 (3):117-122.

25. Wang YN, Shi GL, Zhao LL, et al. Acaricidal Activity of Juglans regia Leaf Extracts on Tetranychus viennensis and Tetranychus cinnabarinus (Acari: Tetranychidae). Journal Economic Entomology. 2007;100:1298-1303. 